\title{
Friedrich Nietzsche’s Homosexuality and Schizophrenia
}

\author{
Robert Dole \\ Université du Québec à Chicoutimi, Québec, Canada
}

\begin{abstract}
This article proposes a new hypothesis about Nietzsche's life and thought. It suggests that the repression of his homosexuality explains both his hatred of Christianity and his descent into insanity. His Biblical religiosity was a fundamental aspect of his essential self, like his homosexuality. He waged a relentless war against both. Yet one cannot be in a permanent battle with oneself without eventually becoming insane.
\end{abstract}

Keywords: Nietzsche, homosexuality, schizophrenia

\section{Introduction}

The publication of Zarathustras Geheimnis by Joachim Köhler in 1989 caused an earthquake among Nietzsche scholars because it documents the story of Nietzsche's homosexuality. The English translation, Zarathustra's Secret, was published in 2002. Nietzsche never had the courage to have homosexual experiences in Germany since being discovered would have meant the end of his career and reputation. At the time, homosexual acts could be punished for up to five years in prison in Germany. Italy had no such law, and thither Nietzsche first betook himself in 1881 at the age of 37 in order to have adventures with young men on the coast near Genoa (Köhler, 2002, p. 167).

\section{Nietzsche’s Homosexuality}

Nietzsche's father died when he was only four years old and he became "the only male in a household consisting of his mother, sister, father's mother and two maiden aunts" (Kaufmann, 1950, p. 22). When he was nine years old, he was still playing with dolls (Köhler, 2002, p. 18). Nietzsche was thus raised by five women from whom he obtained feminine qualities like playing with girlish dolls. This is a certain way to bring up a boy to become a homosexual.

Nietzsche never had any heterosexual experiences, as far as recorded documents can be trusted. His mother and his sister encouraged him to marry, but he always refused, saying: "No doubt marriage is a very desirable state, but as far as I am concerned, it is highly improbable... And do not imagine that I miss anything in my present condition” (Köhler, 2002, p. 100).

Without any sexual desire for women and with society prohibiting homosexual experiences, Nietzsche was forced, against his will, to lead a sexless life.

Robert Dole, Ph.D., Retired Professor of English, Université du Québec à Chicoutimi, Québec, Canada. He also taught English at the Universities of Metz, Bonn and Lodz. He is the author of four books: Le Cauchemar américain, Comment réussir sa schizophrénie, Mon Allemagne and What Rough Beast. 


\section{Nietzsche’s Schizophrenia}

In his brilliant book, Schizophrenia: The Bearded Lady's Disease, Michael Mahoney shows, with numerous examples, that the repression of homosexuality is the most common cause of schizophrenia. He writes about an “intense bisexual conflict” (Mahoney, 2003, p. iii) in which the schizophrenic’s mind is literally torn apart by the war between his superego, which wants to be heterosexual, and his libido, which has strong homosexual desires. This perfectly describes Nietzsche's internal struggle, which he could never admit to himself or to anyone else. Of course he lived in an epoch in which homosexuality was totally taboo and people could not have recourse to psychiatrists and psychologists for an intelligent discussion of their problems.

After a lifetime of repressing his homosexuality and living in constant fear of being discovered, Nietzsche became irreversibly insane in 1889 at the age of 45 and spent the last 11 years of his life in an insane asylum. The most pathetic moment of his altogether pathetic life is when he tells people in his mental hospital in Jena: "My wife, Cosima Wagner, has brought me here” (Kaufmann, 1950, p. 32). He comes out with this lie because it perfectly summarizes his mental illness. He wants to convince himself and those around him that he is really a heterosexual and so he invents the story of being married to a woman. Nothing could be more pitiful.

\section{Nietzsche's Anti-Christianity}

Nietzsche's attack on Christianity is blasphemous, puerile, and hysterical. He calls Jesus "an idiot" (Nietzsche, 1954, p. 601). He makes a mockery of the Sermon on the Mount: "Except we turn back and become as cows, we shall not enter the kingdom of heaven” (Nietzsche, 1954, p. 381). He says: "Christianity is a metaphysics of the hangman” (Nietzsche, 1954, p. 500).

Nietzsche’s most famous sentence is “God is dead” (Nietzsche, 1954, p. 447). This is totally absurd since God's primary quality is that He is eternal. He is the Eternal. The Eternal can no more stop being eternal than the infinite can stop being infinite.

The real reason for Nietzsche's hatred of Christianity is that Christian morality prevented him from having homosexual experiences inside Germany. It is all that simple and all that pathetic.

The great glory of the Christian religion does not consist in the condemnation of sins but rather in the forgiveness of sins. The Christian who knows that God loves him although he is not worthy of this love is a redeemed person. This is grace. This is salvation. That Nietzsche never experienced this fundamental truth of Christianity is at once the cause and the result of his insanity.

\section{Nietzsche's Proto-Nazism}

The Nazis used Nietzsche’s philosophy to justify their ideology. Nietzsche's supporters say that this was an incorrect and dishonest use of Nietzsche's philosophy since Nietzsche had always been opposed to anti-Semitism. But there is more to the Nazis' ideology than their anti-Semitism. The Nazis glorified war and so did Nietzsche.

Obviously referring to Christ, Nietzsche says: "War and courage have accomplished more great things than love of the neighbour" (Nietzsche, 1954, p. 159). "Man should be educated for war, and woman for the recreation of the warrior; all else is folly" (p. 178). "It is the good war that hallows any cause” (p. 359). "One has renounced the great life when one renounces war” (p. 489). "What is happiness? Not peace, but war” (p. 570). 
What is the most outrageous in Nietzsche's glorification of war is that he does not advocate waging war for any particular goal. A revolution to advance socialism or a war to aggrandize Germany's borders has no importance for him. He favours war and violence for their own sake.

To the extent that Nietzsche's glorification of war was adopted by the Nazis in their barbaric ideology, it can be said that Nietzsche shared in the guilt of killing 55 million people during the Second World War.

\section{Conclusion}

I began my life as a philosopher in exactly the same situation in which Nietzsche ended his life as a philosopher: locked up in an insane asylum. He and I struggled with the same three behemoths: Christianity, homosexuality, and schizophrenia. I had been driven insane by a psychiatrist who had tried to cure me of my homosexuality when I was only 16 years old. You can read my story in my book What Rough Beast.

Although I was told by a psychiatrist that I was the most severely mentally ill person who had ever been a patient at the McLean Asylum for the Insane, I have now spent the past 53 years outside mental hospitals without ever consulting a psychiatrist or taking psychiatric medicine. The secret for this miracle is simply that I said "Yes" to homosexuality and I said "Yes" to God. Nietzsche said "No" to both and that is why he became insane.

Socrates famously said that the philosopher's first task is to know himself. Here Nietzsche failed miserably. We know more about him that he did himself. We know why he became insane but he did not.

\section{References}

Dole, R. (2017). What rough beast. London: Austin Macauley.

Kaufmann, W. (1950). Nietzsche: Philosopher, psychologist, antichrist. Princeton: Princeton University Press.

Köhler, J. (2002). Zarathustra's secret. New Haven: Yale University Press.

Mahoney, M. (2003). Schizophrenia: The bearded lady's disease. Bloomington: First Books Library.

Nietzsche, F. (1954). The portable Nietzsche. New York: Viking Press. 